\title{
Development of Fe-based nanocrystalline materials by mechanical alloying(')
}

\author{
J.J. Suñol*, A. González*, L. Escoda* and M.T. Mora**
}

\begin{abstract}
Two alloys, $\mathrm{Fe}_{80} \mathrm{Nb}_{10} \mathrm{~B}_{10}$ and $\mathrm{Fe}_{70} \mathrm{Ni}_{14} \mathrm{Zr}_{6} \mathrm{~B}_{10}$, were produced by mechanical alloying. The formation of the nanocrystallites (about 7-8 $\mathrm{nm}$ at $80 \mathrm{~h} \mathrm{MA}$ ) was detected by X-ray diffraction. After milling for $80 \mathrm{~h}$, differential scanning calorimetry scans show low-temperature recovery processes and several crystallization processes related with crystal growth and reordering of crystalline phases. The apparent activation energy values are $315 \pm 40 \mathrm{~kJ} \mathrm{~mol}^{-1}$ for alloy A, and $295 \pm 20 \mathrm{~kJ} \mathrm{~mol}^{-1}$ and $320 \pm 25 \mathrm{~kJ} \mathrm{~mol}^{-1}$ for alloy B. Furthermore, a melt-spun Fe-based ribbon was mechanically alloyed to obtain a powdered-like alloy. The increase of the rotation speed and the ball-to-powder weight ratio reduces the necessary time to obtain the powdered form.
\end{abstract}

Keywords Fe-based alloys. Mechanical alloying. Nanocrystalline alloys.

\section{Desarrollo de materiales nanocristalinos de base hierro por aleado mecánico}

Resumen

Palabras clave

\begin{abstract}
Dos aleaciones, $\mathrm{Fe}_{80} \mathrm{Nb}_{10} \mathrm{~B}_{10}(\mathrm{~A})$ y $\mathrm{Fe}_{70} \mathrm{Ni}_{14} \mathrm{Zr}_{6} \mathrm{~B}_{10}$ (B), han sido producidas por aleado mecánico. Mediante difracción de rayos $\mathrm{X}$ se ha detectado la formación de nanocristales (7-8 nm a las $80 \mathrm{~h}$ de aleado). Tras molturar $80 \mathrm{~h}$, las curvas calorimétricas muestran procesos exotérmicos asociados a la relajación estructural y al crecimiento cristalino y reordenación de la fase cristalina. Los valores de la energía aparente de activación de las cristalizaciones son 315 $\pm 40 \mathrm{~kJ} \mathrm{~mol}^{-1}$ para la aleación A, y $295 \pm 20 \mathrm{~kJ} \mathrm{~mol}^{-1}$ y $320 \pm 25 \mathrm{~kJ} \mathrm{~mol}^{-1}$ para la aleación B. Por otra parte, se ha procedido a la molturación de una cinta de una aleación de base hierro hasta obtener un material en forma de polvo. El incremento de la velocidad de rotación y de la relación en peso bolas polvo reduce el tiempo necesario para obtener este material.
\end{abstract}

Aleaciones de base hierro. Aleado mecánico. Aleaciones nanocristalinas.

\section{INTRODUCTION}

Nanocrystalline materials, which are defined as materials with grain sizes less than 100 nm have received much attention as advanced materials with improved physical and mechanical properties ${ }^{[1]}$. Mechanical alloying (MA) is one of the solid state reaction techniques by which novel materials may be synthesized from elemental or prealloyed powders. Mechanical alloying involves the synthesis of materials by high-energy ball milling. It was first developed by John Benjamin to produce oxide dispersion strengthened materials ${ }^{[2]}$. Furthermore, mechanical alloying has been reported to be capable of producing non-equilibrium structures including amorphous alloys, nanocrystalline materials and extended solid solutions ${ }^{[3-5]}$. It is also used to obtain alloys subjected to ulterior annealing and consolidation $^{[6 \text { and } 7]}$. Over the past several decades, amorphous and more recently nanocrystalline $\mathrm{Fe}$-based materials have been investigated for applications such as telecommunications, power electronics, micro devices, and so on ${ }^{[8 \text { and } 9]}$.

Although it is known that Fe-based alloys prepared by rapid solidification techniques, in ribbon form, can exhibit superior soft magnetic properties ${ }^{[10]}$, they do not attain a more significant level of applicability because its shape limits their technological use. Mechanical alloying of ribbons is recently applied as an alternative route to obtain powdered materials ${ }^{[11 \text { and } 12]}$. If the original material is amorphous, controlled annealing 
favors the development of a nanocrystalline structure embedded in an amorphous matrix. The MA of ribbons may be a two-step procedure prior to the consolidation or compacting of complicated shape materials in the powder metallurgy industry. In this work, several Fe-based alloys were obtained by mechanical alloying of powders or flakes from ribbons.

\section{EXPERIMENTAL}

Mechanical alloying was carried out in a planetary high-energy ball mill (Fritsch Pulverisette P7) starting from pure element and compound powders $(99.7 \%$ purity $\mathrm{Fe}$, with a particle size under $10 \mu \mathrm{m} ; 99.85 \%$ purity $\mathrm{Nb}$, with a particle size under $74 \mu \mathrm{m} ; 99.6 \%$ purity $B$, with a particle size of $50 \mu \mathrm{m}$, and $99 \%$-purity $\mathrm{Ni}_{7} \mathrm{Zr}_{3}$, with a particle size under $\left.100 \mu \mathrm{m}\right)$. The compositions analyzed in this article were $\mathrm{Fe}_{80} \mathrm{Nb}_{10} \mathrm{~B}_{10}$ and $\mathrm{Fe}_{70} \mathrm{Ni}_{14} \mathrm{Zr}_{6} \mathrm{~B}_{10}$, labeled as $\mathrm{A}$ and $B$ respectively. Each of the powder samples was loaded into a cylindrical $\mathrm{Cr}-\mathrm{Ni}$ stainless-steel vial together with balls of the same material in an argon atmosphere. The ball-to-powder ratio was 5:1. The milling process was performed at a speed of 600 r.p.m. at different milling times until $80 \mathrm{~h}$. Annealing at 300 and $600{ }^{\circ} \mathrm{C}$ was performed in the alloy milled during $80 \mathrm{~h}$.

The Fe-Ni based alloy was produced by meltspinning. The precursors used were pressed powders of elemental $\mathrm{Fe}, \mathrm{Ni}, \mathrm{Si}$ and $\mathrm{Fe}_{3} \mathrm{P}$ compound (to prevent $\mathrm{P}$ sublimation). Pure elements (<99.9 at. \%) and small particle sizes $(<25 \mu \mathrm{m})$ were chosen. The produced samples were in ribbon form with a size of about $0.1 \mathrm{~cm}$ wide and $20 \mathrm{~mm}$ thick. The molten alloy was quenched on the surface of a rapidly spinning (about $30 \mathrm{~m} / \mathrm{s}$ ) Cu wheel. The working atmosphere was inert Ar. Ribbons were cut into pieces about $0.5 \mathrm{~cm}$ large. Several MA runs were performed by modifying some milling conditions such as the ball-to-powder mass ratio (b.p.r. 50:1 and 30:1) and the milling intensity (rotation speeds: 250 r.p.m., 350 r.p.m. and 450 r.p.m.). The size reduction of the ribbons was followed by a sieving method after different milling times, using a $50 \mu \mathrm{m}$ sieve to control the percentage of original ribbon considered as well fractured or powder-like.

The sample thermal characterization was carried out by differential scanning calorimetry (DSC) under an argon atmosphere in Mettler-Toledo DSC30 equipment. The morphology and composition study was performed by scanning electron microscopy (SEM) in a Zeiss DSM960 A equipment coupled with energy dispersive X-ray microanalysis (EDX). The $\mathrm{X}$-ray diffraction $(\mathrm{XRD})$ patterns were carried out in
Siemens D-500 equipment and the analysis of the patterns was performed by Rietveld refinement using MAUD software.

\section{RESULTS AND DISCUSSION}

\subsection{MA of powders}

The morphology of the powders was followed by scanning electron microscopy. The as-milled powders have a relatively broad distribution of particle size, and most particles are found in the range of $5-20 \mathrm{~mm}$. Figure 1 shows the micrographs corresponding to big particles of alloys $A$ and $B$ after $80 \mathrm{~h}$ of milling where the cold-welding process favors the agglomeration and the smooth appearance.

Figure 2 show DSC curves corresponding to alloys $\mathrm{A}$ and $\mathrm{B}$ milled for $80 \mathrm{~h}$. DSC scans show several reactions after a heating procedure. The low temperature, about $160^{\circ} \mathrm{C}$, exothermal process is a signature of stress recovery, which is mainly deformation energy stored during the milling process. Since it occurs in a wide temperature range it is often overlapped with exothermic peaks characteristic of crystallization. In the alloy A, the peak is related to the crystalline growth of the bcc-Fe rich phase, as deduced from X-ray diffraction analysis. The broadness of the main DSC peak, associated to the crystallization, indicates the existence of different Fe-rich environments (bcc- Fe rich inhomogeneous solid solution). The same behavior was previously found in Fe-Nb-B alloys ${ }^{[13]}$. The two overlapped peaks detected in the alloy $\mathrm{B}$ were also found in previous works ${ }^{[14}$ and 15] in Fe-Ni based alloys and are related to more complex crystallization of the same phase.

The apparent activation energy, $E$, for the exothermic processes of alloys milled for $80 \mathrm{~h}$ were evaluated using the Kissinger method: plotting $\ln \left(b / T_{p}^{2}\right)$ versus $1 / T_{p}$, being $b$ the heating rate and $\mathrm{T}_{\mathrm{p}}$ the peak temperature. DSC experiments were carried with heating rates of 2.5, 5, 10, 20 and $40 \mathrm{~K} \mathrm{~min}^{-1}$. The values obtained for the activation energy $\mathrm{E}$ were $315 \pm 40 \mathrm{~kJ} \mathrm{~mol}^{-1}$ for alloy $\mathrm{A}$, and 295 $\pm 20 \mathrm{~kJ} \mathrm{~mol}^{-1}$ and $320 \pm 25 \mathrm{~kJ} \mathrm{~mol}^{-1}$ for alloy B. Energy values of 320,370 and $351 \mathrm{~kJ} / \mathrm{mol}$ have been found for $\mathrm{Fe}_{87} \mathrm{Zr}_{7} \mathrm{~B}_{6}, \mathrm{Fe}_{86} \mathrm{Zr}_{7} \mathrm{~B}_{6} \mathrm{Cu}_{1}{ }^{[16]}$ and $\mathrm{Fe}_{85.5} \mathrm{Zr}_{4} \mathrm{Nb}_{4} \mathrm{~B}_{5.5} \mathrm{Al}_{1}{ }^{[17]}$ in previous works. The obtained values seem reasonable to be associated with a grain growth process.

Structural evolution was followed by XRD. The lattice parameter, crystalline size and microstrain were determined using Rietveld refinements with RB values lower than $5.7 \%$ in all cases. The lattice parameter calculated for the powders milled for 

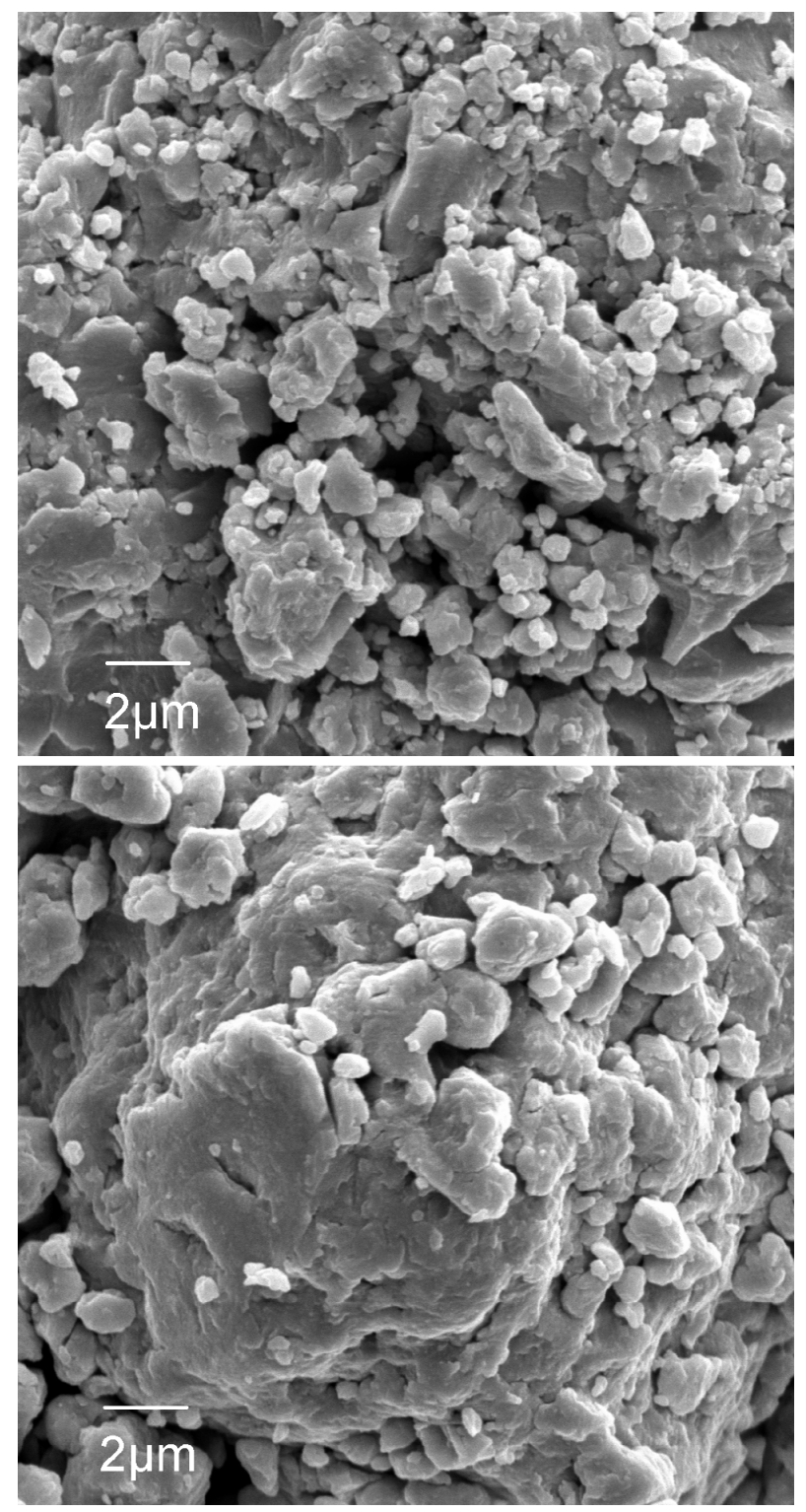

Figure 1. SEM micrographs corresponding to alloys A (left) and B (right) milled for $80 \mathrm{~h}$.

Figura 1. Micrografías obtenidas mediante SEM de las aleaciones $A$ (izquierda) y $B$ (derecha) molturadas durante $80 \mathrm{~h}$.

$80 \mathrm{~h}$ were $a=0.2848 \pm 0.0003 \mathrm{~nm}$ and $a=0.2854 \pm$ $0.0003 \mathrm{~nm}$ in alloys $\mathrm{A}$ and $\mathrm{B}$, respectively. This values are somewhat lower than that of the pure bcc-Fe phase, indicating dissolution of other elements. It is known that the dissolution of boron in the Fe lattice causes a decrease of the lattice by 0.02-0.03\% for every 1 at. $\%$ of boron ${ }^{[18]}$. Figure 3 shows the values corresponding to crystallite size and microstrain. The values indicate an asymptotic behavior of the parameters as increasing the milling time, and the final state remains nanocrystalline. In essence, it is enough to mill for about $20 \mathrm{~h}$ to reach a crystallite size close to where

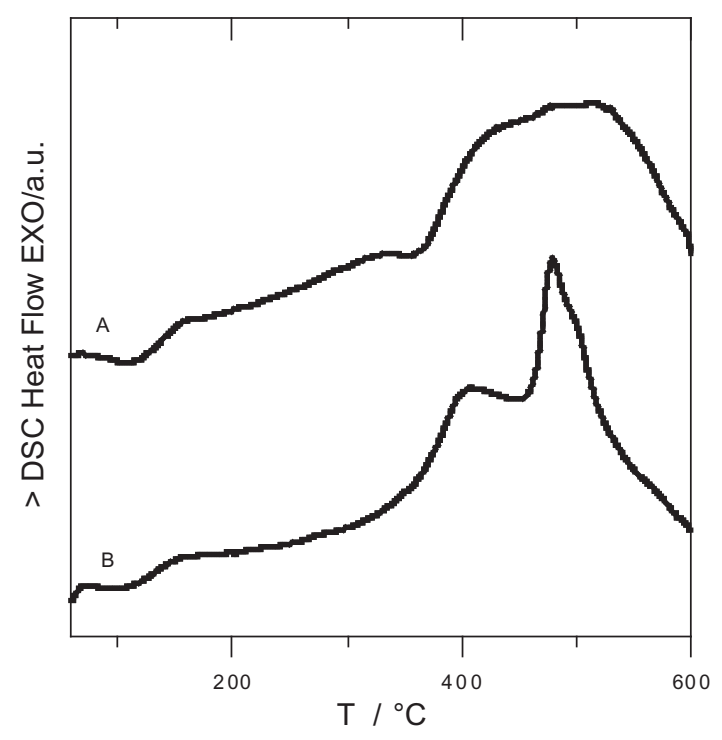

Figure 2. DSC curves of alloys $A$ and $B$ milled for $80 \mathrm{~h}$ at a heating rate of $10 \mathrm{~K} / \mathrm{min}$.

Figura 2.Curvas DSC, a una velocidad de calentamiento de $10 \mathrm{~K} / \mathrm{min}$, de las aleaciones $A$ y $B$ tras ser molturadas durante $80 \mathrm{~h}$.

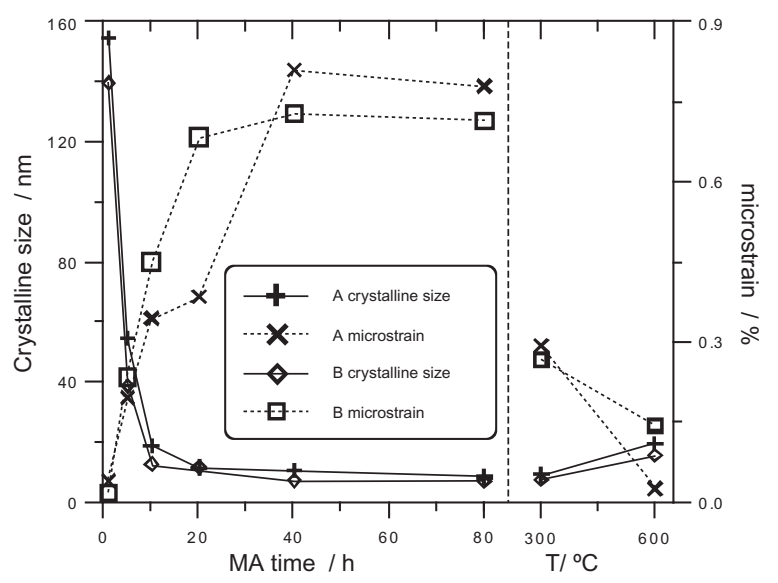

Figure 3. X-ray diffraction analysis. Crystallite size and strain as a function of milling time and annealing temperature. Annealing was performed in alloy milled during $80 \mathrm{~h}$.

Figura 3. Análisis de los difractogramas de rayos X. Tamaño cristalino e índice de microdeformaciones en función del tiempo de molienda y de la temperatura de tratamiento. El tratamiento térmico se ha realizado en las muestras molturadas durante $80 \mathrm{~h}$.

single-domain magnetic properties come into play ${ }^{[19]}$. The $80 \mathrm{~h}$ as-milled alloy consisted primarily of metastable bcc-Fe rich nanocrystals $(\approx 7-8)$ nm mean 
diameter. Values obtained for microstrain index increase with the milling time as expected. Annealing at 300 and $600{ }^{\circ} \mathrm{C}$ was performed in alloy milled during $80 \mathrm{~h}$. Furthermore, as shown in figure 3 , results for annealed materials confirm that the low temperature process $\left(<300{ }^{\circ} \mathrm{C}\right)$ is related to structural relaxation and the crystalline processes detected at higher temperature are related to crystalline growth. Nevertheless, the alloy after annealing at $600{ }^{\circ} \mathrm{C}$ is still nanocrystalline (20-30 $\mathrm{nm}$ ).

Figure 4 compares the tendency of microstrain and crystalline size values. In a first step of the MA process, the microstrain increases as well as the crystalline size decreases. Strain shows weak grain size dependence typical for dislocation-controlled deformation process of large grained polycrystals. In a second step, the microstrain increases whilst crystalline size remains nearly constant. In a third step, only the crystallite size diminishes. Those results are in good agreement with previous studies where the crystallite size and microstrain values are related to milling conditions ${ }^{[20}$ and 21$]$.

\subsection{MA of ribbon flakes}

It is necessary to consolidate the nanocrystalline powders into bulk form for the needs of practical applications. However, consolidation of nanocrys-

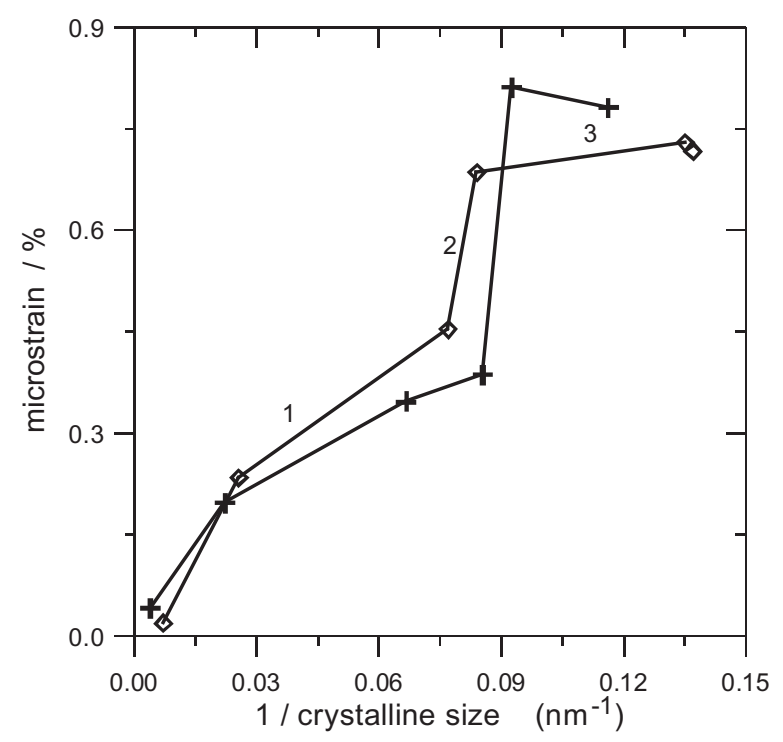

Figure 4. X-ray diffraction analysis: Crystalline size and microstrain evolution.

Figura 4. Análisis de los difractogramas de rayos $X$. Evolución de la relación entre el tamaño cristalino y el índice de microdeformaciones. talline powders into bulk, full density compacts while retaining nanoscale grain size is obviously a major challenge ${ }^{[22]}$. If the original material is amorphous, it can be easier to obtain a nanocrystalline material after consolidation. As an example, bulk amorphous and nanocrystalline FeZrNbB alloys were prepared by consolidating amorphous powders crushed from asquenched ribbons ${ }^{[23]}$. As this work only deals with the milling process, complementary works analyzing the consolidation of resulting material will be necessary.

As increasing the milling time, the ribbon pieces were fractured, and the final form were a powderedlike material. As an example, figure 5 shows two micrographs corresponding to an as-quenched ribbon milled at 350 r.p.m. after 2 and 16 h. For the lowest milling time sample, the ribbons shape is clear, but for the highest milling time sample, the material shows a powdered-like morphology. Furthermore, when increasing the milling energy, the powdered form appears at low milling time. Similar results were found in Fe-based milled ribbons ${ }^{[24]}$. The results show only slight $(<0.12$ at. \%) Cr contamination from the milling tools in all alloys after $80 \mathrm{~h}$ of MA. Thus, minor influence of $\mathrm{Cr}$ contamination on material properties is expected.

The milling energy increases with the rotation speed and the ball-to-powder weight ratio. To obtain a great amount of the ribbons in a powder form, the sieving criterion considered was to continue with the milling procedure until the weight percentage of big particles $(>50 \mu \mathrm{m})$ was lower than $5 \%$. Figure 6 shows the percentage of alloy in ribbon form using the sieving method as a function of the milling time. Results show a general diminution of the milling time spent, $t_{\mathrm{m}}$, with the increase of the rotation speed or the ball-to-powder weight ratio. Both parameters are related to the energy associated to the milling process. As expected, when increasing the total energy involved in the ribbon fracture, the time spent decreases. A lower milling time favors the technological reliability of this combined route. For ribbon flakes milled at 250, 350 and 450 r.p.m. the times were $24 \mathrm{~h}, 16 \mathrm{~h}$ and $6 \mathrm{~h}$, respectively. On the other hand, only slight differences due to the ballto-powder weight ratio were found.

A first approach to a technological parameter associated to this process could be $t_{\mathrm{m}}$. Nevertheless, since this time may differ significantly from the necessary time (at which the weight percentage achieves the $5 \%$ ) we suggest an alternative parameter. This coefficient, C, is defined as the product of the milling time, spent, $t_{m}$, and the weight percentage of the remaining big $(>50 \mu \mathrm{m})$ particles. The best condition corresponds to the lowest value. Figure 7 shows the results obtained for every sample. 

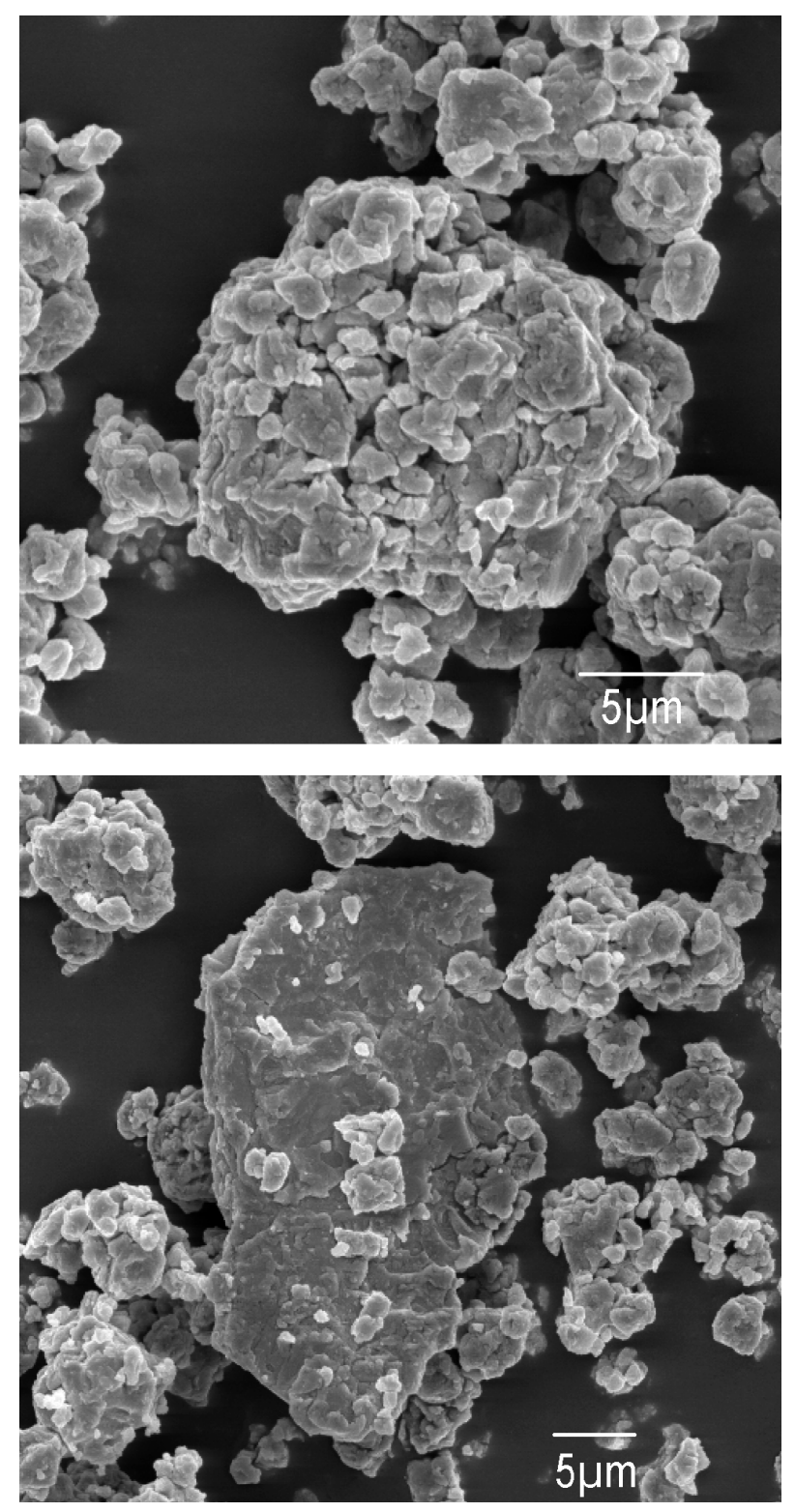

Figure 5. SEM micrographs corresponding to ribbon flakes milled at 350 r.p.m. for $2 \mathrm{~h}$ (left) and $16 \mathrm{~h}$ (right).

Figura 5. Micrografías obtenidas mediante SEM de virutas de la cinta molturada a 350 r.p.m. durante $2 h$ (izquierda) y $16 h$ (derecha).

As increasing the milling intensity the coefficient value diminishes. We can state that the influence of the milling rotation speed is higher than that of the ball-to-powder weight ratio.

\section{CONCLUSIONS}

Two Fe-rich rich nanocrystalline alloys were produced by mechanical alloying. The activation

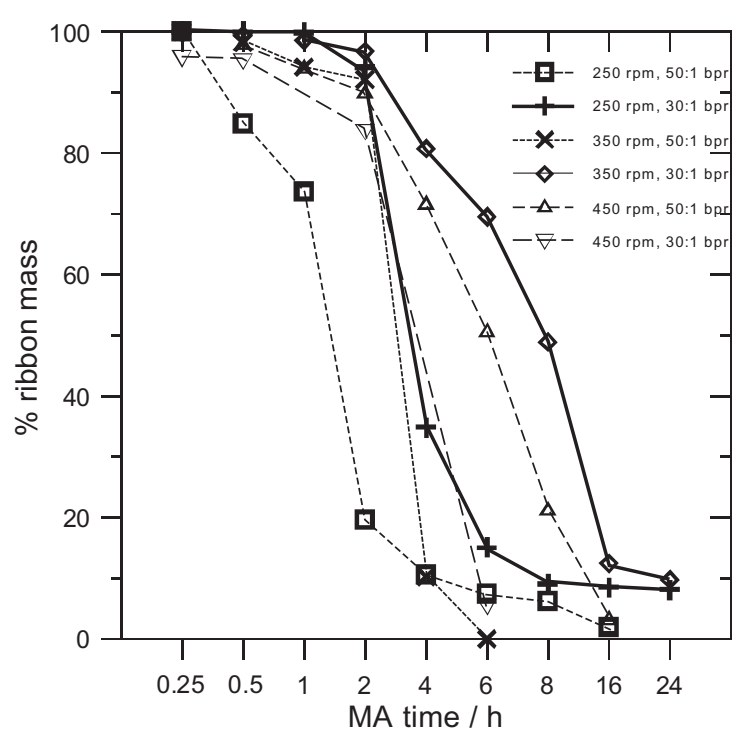

Figure 6. Mass percentage in ribbon form $(>50$ $\mu \mathrm{m})$ as a function of milling time and milling conditions.

Figura 6: Porcentaje másico de virutas de cinta (>50 $\mu \mathrm{m}$ ) en función del tiempo y de las condiciones de molturado.

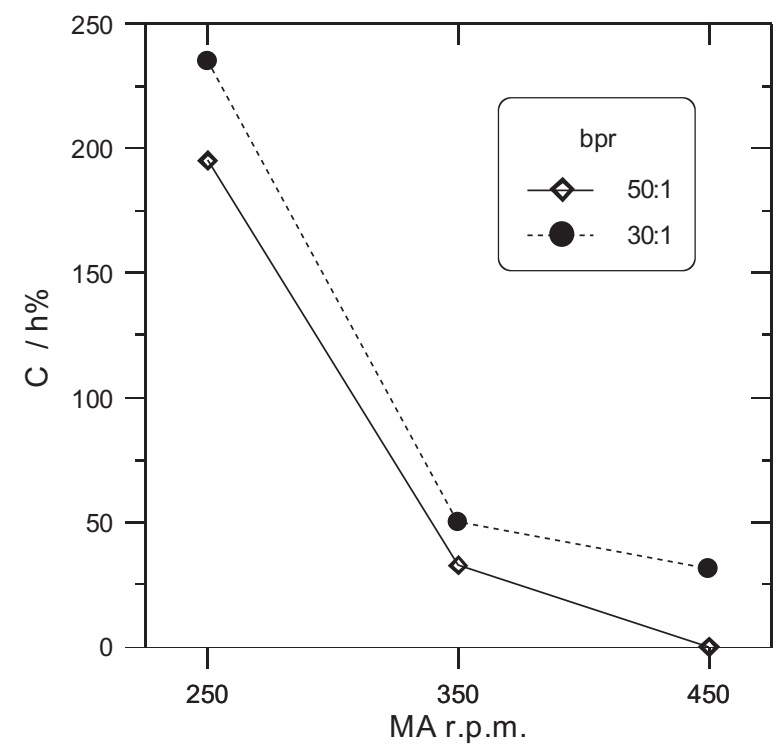

Figure 7. Evolution of parameter $C$ versus milling rotation speed.

Figura 7. Evolución del parámetro $C$ en función de la velocidad de rotación.

energy values of the crystallization processes detected in DSC scans were $315 \pm 40 \mathrm{~kJ} \mathrm{~mol}^{-1}$ for alloy A, and $295 \pm 20 \mathrm{~kJ} \mathrm{~mol}^{-1}$ and $320 \pm 25 \mathrm{~kJ} \mathrm{~mol}^{-1}$ for alloy $\mathrm{B}$, which are values associated with grain growth. 
DEVELOPMENT OF FE-BASED NANOCRYSTALLINE MATERIALS BY MECHANICAL ALLOYING DESARROLLO DE MATERIALES NANOCRISTALINOS DE BASE HIERRO POR ALEADO MECÁNICO

Structural evolution was followed by XRD using Rietveld refinement. The $\mathrm{RB}$ values of the refinement were always lower than $5.7 \%$. The lattice parameter calculated for the powders milled for $80 \mathrm{~h}$ were $a=0.2848 \pm 0.0003 \mathrm{~nm}$ and $a=0.2854 \pm 0.0003 \mathrm{~nm}$ for alloys $\mathrm{A}$ and $\mathrm{B}$, respectively, indicating dissolution of other elements.

Furthermore, flakes were subjected to mechanical alloying to obtain a powdered-like material that can be the precursor of ulterior compaction. We defined a technological coefficient associated to this process, the product of the lowest-limit milling time (the necessary time to obtain a weight percentage of particles with particle size higher than $50 \mu \mathrm{m}$ lower than 5\%), and this percentage. From this parameter values, we can infer that the influence of the milling rotation speed is higher than that of the ball-to-powder weight ratio.

\section{Acknowledgments}

Financial support from MICYT and FEDER (projects No. MAT2003-08271-C02-02 and MAT2006-13925C02-02) and DURSI (SGR2005-00201) is acknowledged.

\section{REFERENCES}

[1] H. Gleiter, Prog. Mater. Sci. 33 (1989) 223-315.

[2] J.S. Benjamin, Metall. Trans. 1 (1970) 2943.

[3] E. Gaffet, N. MalhourouX And M. AbDELLAOUI, J. Alloys Compd. 194 (1993) 339-360.

[4] C.C. Koch And J.D. WhitTenberger, Intermetallics, 4 (1996) 339-355.

[5] J. Balogh, T. Kemeny, I. Vincze, L. Budjoso, L. Toth And G. Vincze, J. Apply. Phys. 77 (1995) 4997-5003.

[6] F.G. Cuevas, J.M. Montes, J. Cintas And J.M. GallaRDO, Rev. Metal. Madrid 41 (2005) 83-88.

[7] M. López, C. CAmurri, V. Vergara and J.A.
JimÉNEZ, Rev. Metal. Madrid 41 (2005) 308 312.

[8] M.E. MChenry, M.A. Willard AND D.E. Laughlin, Prog. Mater. Sci. 44 (1999) 291-433.

[9] K. TAdakate, A. Kojima, A. Makino And A. INOUE. Scripta Mater. 44 (2001) 1401-1405.

[10] J.S. GARITAONANDIA, P. GORRIA, L. FERNÁNDEZ-BARQUín AND J.M. BARANDIARÁN, Phys. Rev. B 26-9 (2000) 6150-6155.

[11] M. PEKALA, M. JACHIMOWICZ, V.I. FADEEVA, H. Matija And A. Grabias, J. Non-Cryst. Solids 287 (2001) 380-384.

[12] J.J. SuÑOL, A. GONZALEZ, T. PRAdell, P. BRUNA, M.t. Mora And N. ClaVaguera. Mater. Sci. Eng. A 375 (2004) 881-887.

[13] J.J. SUÑOL, A. GONZÁlEZ AND J. SAURINA, J. Therm. Anal. Calorim. 72 (2003) 329-335.

[14] J.J. SUÑOl, N. Clavaguera AND M.t. ClaVAGUERA-MORA, J. Non-Cryst. Solids 287 (2001) 114-119.

[15] J.J. SuÑol, T. PRAdELl, N. Clavaguera AND M.T. Clavaguera-Mora, J. Metast. Nanocryst. Mater. 10 (2001) 525-530.

[16] P. Duhaj, I. MatKo, P. Svec, J. Sitek AND D. JANICKOVIC, Mater. Sci. Eng. B 39 (1996) 208215.

[17] A-H. Mansourand J. BARry, J. Mater. Sci. Lett. 17 (1998) 1125-1127.

[18] A.L. GreER, Acta Metall. 30 (1982) 171-192.

[19] B.D. CULLITY, Introduction to Magnetic Materials, Addison-Wesley Publishing Company, Eds., Massachusetts, USA, 1972.

[20] R. JuÁreZ, J.J. SuÑol, R. BERlAnGA, J. BONASTRE, L. EsCODA, J. Alloys Compd. (2007) 472-476.

[21] I. BÖRNER AND J. ECKERT, Mater. Sci. Eng. A 226/228 (1997) 541-545.

[22] W. LU, L. YANG, B. YAN, W-H. HuANG AND B. LU, J. Magn. Magn. Mater. 292 (2005) 299-303.

[23] W. LU, L. YANG, B. YAN, W-H. HUANG AND B. LU, J. Alloy Compd. 413 (2006) 85-89.

[24] J.J. Suñol, A. González, P. Bruna, T. Pradell, N. Clavaguera And M.T. Mora, Mater. Sci. Forum 426 (2003) 1927-1932. 